\title{
Pengaruh Metode RGEC (Risk Profile, Good Corporate Governance, Earnings, dan Capital) Pada Nilai Perusahaan
}

\author{
Desak Made Gita Lestari ${ }^{1}$ \\ Made Gede Wirakusuma ${ }^{2}$
}

${ }^{1}$ Fakultas Ekonomi dan Bisnis Universitas Udayana (Unnud), Bali, Indonesia e-mail : desakgita@gmail.com / telp. +6287 861385019

${ }^{2}$ Fakultas Ekonomi dan Bisnnis Universitas Udayana (Unud), Bali, Indonesia

\begin{abstract}
ABSTRAK
Penelitian ini bertujuan untuk mengetahui pengaruh dari penerapan metode RGEC pada nilai perusahaan pada perbankan. Penelitian ini memiliki 43 bank yang terdaftar di Bursa Efek Indonesia selama 3 tahun berturut-turut dari tahun 20142016, sehingga total sampel sebanyak 129 sampel dengan menggunakan teknik purposive sampling. Dari hasil analisis yang diperoleh dengan menggunakan teknik analisis linier berganda, didapatkan bahwa variabel risk profile berpengaruh negatif pada nilai perusahaan, sedangkan variabel good corporate governance, earnings, dan capital berpengaruh positif pada nilai perusahaan.
\end{abstract}

Kata kunci: risk profile, GCG, earnings, capital, nilai perusahaan

ABSTRACT
This research is purposed to determine the effect of the application of RGEC method to the value of the firm in the banking system. This research has 43 banks listed in Indonesia Stock Exchange for 3 consecutive years from 2014-2016, so the total sample is 129 samples by using purposive sampling method. From the analysis result obtained by using multiple regression analysis, it is found that risk profile variable has a negative effect on value of the firm, however the variable of good corporate governance, earnings, and capital has positive effect on value of the firm.

Keywords: risk profile, GCG, earnings, capital, value of the firm 


\section{PENDAHULUAN}

Perbankan Indonesia sempat mengalami krisis kepercayaan dari masyarakat terhadap bank, yaitu pada saat Indonesia mengalami krisis moneter pada tahun 1998 yang diakibatkan oleh menurunnya nilai tukar rupiah terhadap nilai tukar dollar AS. Pada tahun 2008, Amerika Serikat sempat mengalami krisis keuangan global yang berimbas ke seluruh dunia yang mengakibatkan perbankan di Indonesia sulit menjalankan kewajiban mereka sebagai lembaga keuangan (Brahmananda dan Suputra, 2017). Krisis keuangan global pada tahun 2008 juga mempengaruhi kinerja keuangan bank yang berkaitan dengan tingkat kesehatan suatu bank.Indonesia yang merupakan negara berkembang membutuhkan dana yang cukup besar untuk melaksanakan pembangunan nasional. Kesejahteraan masyarakat merupakan suatu konsep yang dapat menunjukkan ukuran keberhasilan pembangunan pada suatu wilayah, salah satunya dapat dilihat dari pendapatan yang diperoleh oleh masyarakat itu sendiri.

Adanya badan usaha maka peningkatan pendapatan melalui kegiatan perekonomian dapat meningkatkan kualitas hidup manusia. Ada beberapa jenis badan usaha, seperti Badan Usaha Milik Negara (BUMN) dan Badan Usaha Milik Swasta (BUMS). BUMN menurut Undang-Undang Nomor 19 Tahun 2003 adalah badan usaha yang seluruh atau sebagian besar modalnya dimiliki oleh negara melalui penyertaan secara langsung yang berasal dari kekayaan negara yang dipisahkan. BUMS merupakan badan usaha yang seluruh usahanya dikuasai dan dikelola oleh pihak swasta diluar pemerintah, dimana modalnya dimiliki oleh pihak swasta tersebut. Perbankan adalah lembaga keuangan yang berperan penting 
bagi kegiatan perekonomian suatu negara, karena dengan kegiatan perkreditan dan berbagai jasa yang ditawarkan oleh bank maka dapat melayani berbagai kebutuhan pada sektor ekonomi dan perdagangan (Kaligis, 2013).

Menurut Undang-Undang Republik Indonesia No. 10 Tahun 1998 tentang Perbankan, perbankan adalah segala sesuatu yang menyangkut tentang bank, mencakup kelembagaan, kegiatan usaha, serta cara dan proses dalam melaksanakan kegiatan usahanya. Tujuan dasar pengelolaan bank adalah mewujudkan keuntungan, sebagai syarat kritis untuk menjalankan bisnis (Menicucci dan Paolucci, 2016). Sebagai bentuk tanggung jawab Bank Indonesia terhadap tingkat kesehatan bank, Bank Indonesia menetapkan Peraturan Bank Indonesia No. 13/1/PBI/2011 dengan menggunakan pendekatan RGEC (Risk Profile, Good Corporate Governance, Earnings, Capital). Bank Indonesia sebagai bank sentral mengeluarkan kebijakan mengenai analisis kesehatan bank yang diatur di dalam Surat Edaran Bank Indonesia No. 13/24/DPNP Tahun 2011 tentang Penilaian Tingkat Kesehatan Bank Umum yang mengharuskan bank umum melakukan penilaian sendiri (self assessment) dengan menggunakan pendekatan RGEC. Metode RGEC ini merupakan peraturan yang menggantikan metode yang terdahulu, yaitu Peraturan Bank Indonesia No. 6/10/PBI/2004 tanggal 31 Mei 2004 mengenai Sistem Penilaian Tingkat Kesehatan Bank Umum yang menggunakan 6 faktor yang disebut CAMELS (Capital, Asset Quality, Management, Earnings, Liquidity, and Sensitivity) (www.bi.go.id).

Ukuran bank dikatakan dapat mempengaruhi nilai perusahaan karena baik secara internal maupun eksternal, sumber pendanaan akan mudah diperoleh 
Desak Made Gita Lestari dan Made Gede Wirakusuma. Pengaruh ...

sehubungan dengan semakin besar ukuran atau skala perusahaan. Menurut Setiani (2013) nilai perusahaan merupakan suatu hal yang penting bagi manajer dan investor. Harga saham sering terkait dengan nilai perusahaan yang mana merupakan persepsi investor terhadap perusahaan (Hermuningsih dan Wardani, 2009).

Berdasarkan uraian diatas, maka dapat dirumuskan permasalahan dalam penelitian ini, yaitu 1) Apakah risk profile berpengaruh pada nilai perusahaan?; 2) Apakah GCG berpengaruh pada nilai perusahaan?; 3) Apakah earnings berpengaruh pada nilai perusahaan? dan; 4) Apakah capital berpengaruh pada nilai perusahaan?

Riset ini diharapkan mampu memberikan manfaat, baik secara teoritis maupun praktis. Secara teoritis, penelitian ini diharapkan dapat memberikan bukti empiris, tambahan referensi, maupun ilmu pengetahuan terkait dengan nilai perusahaan pada perbankan yang memiliki regulasi khusus serta untuk menanbah informasi mengenai tingkat kesehatan bank. Penelitian ini juga bertujuan untuk membuktikan bagaimana teori keagenan mendasari variabel independen yang digunakan pada hubungannya dengan nilai perusahaan. Secara praktis, penelitian ini diharapkan dapat memberikan informasi kepada investor untuk membantu pengambilan keputusan dalam menilai suatu perusahaan perbankan. Penelitian ini juga diharapkan dapat menjadi referensi bagi perusahaan agar dapat mengetahui sebenarnya bagaimana tingkat kesehatan suatu bank.

Jensen dan Meckling (1976) menjelaskan teori keagenan adalah konsep yang menjelaskan hubungan kontraktual antara prinsipal dan agen, yaitu antara 
dua atau lebih individu, kelompok atau organisasi.Prinsipal di dalam suatu perusahaan adalah pemegang saham (stakeholder) dan agen adalah Chief Executive Officer (CEO). Teori keagenan menjelaskan peran eksekutif di perbankan (agent) kepada pemilik modal (principal) mengenai usaha pemaksimalan tingkat kesehatan bank yang diperoleh dari keputusan yang diambil untuk menghasilkan kompensasi atas prestasi yang didapatkan. Keputusan keuangan yang diambil akan menghasilkan hasil maksimum bagi perusahaan yang dapat dilihatdari baiknya rasio kesehatan perbankan yang dihasilkan. Setyapurnama dan Nopratiwi (2004) mengemukakan hubungan keagenan bisa memunculkan masalah ketika pihak yang bersangkutan memiliki tujuan beda.

Teori sinyal menggambarkan hubungan RGEC pada nilai perusahaan perbankan.Spence (1973) mengemukakan bahwa dengan memberikan suatu sinyal, pihak pengirim berupaya memberikan informasi relevan yang bisa dimanfaatkan pihak penerima, kemudian pihak penerima akan menyelaraskan prilaku dan pemahamannya terhadap sinyal tersebut. Teori sinyal menjelaskan bahwa pemberian sinyal dilakukan oleh manajer untuk mengurangi asimetri informasi (Jama'an, 2008). Informasi yang diumumkan sebagai suatu pemberitahuan akan memberi sinyal untuk investor dalam mengambil keputusan dalam berinvestasi (Jogiyanto, 2014). Bila pemberitahuan itu menghasilkan nilai yang positif, maka manajer berharap pasar dapat bereaksi ketika pemberitahuan itu diterimaoleh pasar. Hasil riset yang diperoleh akan menjadi informasi bagi investor dalam menganalisis kinerja dari perbankan untuk kepentingan investor dalam berinvestasi. Signalling theory menjelaskan bagaimana perusahaan mengeluarkan 
sinyal berupa informasi yang dapat menjelaskan keadaan perusahaan tersebut lebih baik dibandingkan dengan perusahaan lainnya (Pratama dan Wirawati, 2016). Menurut Dewi dan Wiratmaja (2017), teori sinyal mengemukakan bagaimana perusahaan menyampaikan sinyal ke pemakai laporan keuangan dimana sinyal yang diterima bersifat negatif atau positif.

Nilai perusahaan adalah kondisi tertentu yang sudah dicapai perusahaan yang menunjukkan bagaimana kepercayaan masyarakat terhadap perusahaan tersebut setelah melalui berbagai kegiatan dari perusahaan tersebut didirikan sampai saat ini. Pencapaian maksimal dari nilai perusahaan untuk meningkatkan kesejahteraan pemegang saham (Wida \& Suartana, 2014). Tujuan dari sebuah perusahaan selain untuk memaksimalkan kesejahteraan shareholder-nya, juga memperhatikan kepentingan stakeholder (Keown, et al., 2011). Nilai perusahaan merupakan nilai jual suatu perusahaan dalam pasar modal, atau dengan kata lain, nilai perusahaan dapat dicerminkan pada harga saham perusahaan di pasar. Jika harga saham cenderung stabil dan terus meningkat, maka investor yang dalam hal ini adalah nasabah akan tertarik untuk menanamkan modalnya pada perusahaan atau bank tersebut dan akan berdampak pada nilai perusahaan yang ikut meningkat juga. Nilai pasar perusahaan adalah asumsi pasar yang berasal dari nasabah, stakeholder, dan investor mengenai keadaan perusahaan yang tergambar pada nilai pasar saham perusahaan yang dapat menjadi skala nilai perusahaan (Sisharini, 2013).

Menurut UU No. 10 tahun 2008 mengenai perbankan, "Bank adalah badan usaha yang menghimpun dana dari masyarakat dalam bentuk simpanan dan 
menyalurkannya kepada masyarakat dalam bentuk kredit, dan atau bentuk-bentuk lainnya dalam rangka meningkatkan taraf hidup rakyat banyak". Fungsi utama bank adalah menghimpun dana dari masyarakat dan menyalurkannya kembali kepada masyarakat untuk berbagai tujuan atau sebagai financial intermediary (Budisantoso dan Nuritomo, 2014).

Risk Profile adalah penilaian atas risiko inheren dan tingkat dalam menerapkan manajemen risiko dalam aktivitas operasional perbankan yang dilakukan terhadap 8 risiko, antara lain risiko pasar, risiko kredit, risiko operasional, risiko strategi, risiko kepatuhan, risiko likuidias, risiko hukum, serta risiko reputasi. Peneliti memakai indikator risiko kredit. Risiko kredit adalah suatu kerugian yang disebabkan karena ketidakmampuan dari debitur atau pihak lain untuk memenuhi kewajibannya kepada bank.

Forum for Corporate Governance in Indonesia - FCGI (2001) mengartikan corporate governance sebagai suatu peraturan untuk mengatur keterkaitan antar manajer, pemegang saham, pemerintah, kreditur, staf, serta pihak lain yang berkepentingan yang terkait hak dengan kewajiban ataupun dengan kata lain sebagai suatu mekanisme yang mengatur dan mengendalikan perusahaan. Berdasarkan ketentuan Bank Indonesia mengenai penilaian tingkat kesehatan bank umum dengan menggunakan pendekatan risiko (Risk Based Bank Rating), penilaian pelaksanaan GCG berlandaskan atas 5 prinsip dasar GCG yang dikategorikan pada suatu governance system yang terdiri dari 3 bagian governance, yaitu (1) governance structure meliputi pelaksanaan tugas dan tanggungjawab Dewan Komisaris dan Dewan Direksi beserta kelengkapan dan 
Desak Made Gita Lestari dan Made Gede Wirakusuma. Pengaruh ...

pelaksanaan tugas-tugas komite; (2) governance process meliputi fungsi kepatuhan bank, penanganan benturan kepentingan, penerapan fungsi audit intern dan ekstern, penerapan manajemen risiko termasuk sistem pengendalian intern, penyediaan dana kepada pihak terkait dan dana besar, serta rencana strategis bank dan; (3) governance outcome meliputi transparansi kondisi keuangan dan non keuangan, laporan pelaksanaan GCG yang memenuhi prinsip transparency, accountability, responsibility, independency, dan fairness (TARIF).

Earnings bertujuan untuk mengetahui kemampuan bank dalam menghasilkan laba, dan untuk mengukur tingkat efektifitas manajemen dalam menjalankan operasional perusahaannya. Tujuan capital adalah memastikan jika dalam kinerjanya, bank mengalami kerugian, maka bank mempunyai ketersediaan modal guna menutupi kerugian yang terjadi. Modal merupakan dasar kegiatan operasional perusahaan yang telah dihitung perusahaan dengan menambah laba atau mengurangi kerugian perusahaan.

Risiko perbankan yang rendah dapat mengindikasikan bahwa manajemen sudah mampu dalam mengatasi dan meminimalisir risiko inheren dalam perbankan. Kemampuan manajer tersebut menunjukan bahwa prospek kedepannya dari bank tersebut akan berada dalam kondisi baik. Adanya informasi risk profile yang rendah dalam laporan keuangan, maka akan memberikan sinyal kepada stakeholder dan akan direspon melalui harga saham perbankan di pasar yang berpengaruh ke tingkat kesehatan bank. Peningkatan harga saham tersebut akan berdampak pada meningkatnya nilai perusahaan, sehingga akan menghasilkan hubungan negatif antara nilai risk profile terhadap nilai perusahaan 
pada perbankan. Pernyataan ini didukung oleh penelitian sebelumnya, yaitu Agustini dan Wardoyo (2015) dan Bertinetti, et al., (2013) menyimpulkan besarnya risiko perbankan akan mengakibatkan penurunan pada nilai perusahaan perbankan.

$\mathrm{H}_{1}$ : Risk Profile berpengaruh negatif pada nilai perusahaan.

Berdasarkan ketentuan Bank Indonesia, penilaian pelaksanaan GCG didasari oleh 5 prinsip dasar GCG dikategorikan menjadi 3 aspek governance, yaitu governance structure, governance process, dan governance outcome. Penilaian GCG dengan governance system dapat memberi sinyal bahwa kinerja perusahaan berjalan optimal dengan kontrol yang memadai, selain itu penilaian ini juga akan memberikan sinyal positif bagi investor sehingga investor berani untuk menanamkan modalnya yang akan berdampak pada peningkatan harga saham. Adanya peningkatan harga saham ini dapat memproyeksikan kinerja perusahaan yang semakin baik dan berdampak pada nilai perusahaan perbankan. Pernyataan ini didukung oleh penelitian sebelumnya, yaitu Gherghina (2015) yang menemukan bahwa rating GCG yang diberikan kepada perusahaan go public di Colombia mampu memengaruhi peningkatan nilai perusahaan. Hasil penelitian Randy dan Juniarti (2013) menyatakan bahwa GCG yang diukur dengan GCG score berpengaruh signifikan terhadap nilai perusahaan.

$\mathrm{H}_{2}$ : Good Corporate Governance berpengaruh positif pada nilai perusahaan.

Earnings merupakan kemampuan perusahaan dalam menghasilkan laba bersih dari aktivitas yang dilakukan pada suatu periode akuntansi. Kinerja perbankan yang baik dapat dilihat dari kemampuannya dalam memerdayakan aset 
Desak Made Gita Lestari dan Made Gede Wirakusuma. Pengaruh ...

yang dimiliki untuk menghasilkan laba yang optimal, namun ada beberapa investor yang menganggap jika perusahaan paling baik dilihat dari profitabilitasnya. Keuntungan yang diperoleh akan menggambarkan perusahaan sanggup memaksimalkan pengendalian operasional sehingga kelangsungan usaha untuk kedepannya akan lebih terjamin. Saat perusahaan menghasilkan keuntungan yang tinggi dibandingkan periode sebelumnya, maka pemangku kepentingan akan mendapat sinyal positif dari informasi tersebut. Earnings (rentabilitas) dapat diproyeksikan dengan rasio ROA (Utami, 2015). Pernyataan ini didukung oleh penelitian sebelumnya, yaitu Arifin dan Astuti (2013) yang mengemukakan kenaikan profitabilitas dilihat dari ROA dan ROE pada perbankan Indonesia dalam rentang waktu 2008-2012 dapat menaikkan nilai perusahaan dengan signifikan. Selain itu, Hidayat (2014) juga melakukan penelitian mengenai hubungan antara profitabilitas dengan nilai perusahaan, diperoleh hubungan yang positif.

$\mathrm{H}_{3}$ : Earnings berpengaruh positif pada nilai perusahaan.

Ketika perusahaan mempunyai modal yang cukup guna menutupi semua risiko aset yang dimiliki, maka informasi yang dterima oleh investor menjadi informasi positif dari kemampuan perbankan tersebut. Menilai kecukupan modal (capital) yang dimiliki bank dapat diproyeksikan dengan rasio CAR (Capital Adequancy Ratio). CAR (Capital Adequancy Ratio) adalah salah satu proyeksi capital dalam menilai modal yang cukup yang dimiliki bank untuk mencukupi jika ada kegagalan pemberian kredit (Utami, 2015). Sesuai dengan regulasi perbankan, ketentuan batas minimum CAR adalah $8 \%$. Kecukupan modal yang 
sesuai dapat menggambarkan bahwa perusahaan dapat menjalankan operasionalnya, baik untuk menutupi penurunan aktiva atau meningkatkan laba perbankan. Pernyataan ini didukung oleh penelitian sebelumnya, yaitu penelitian dari Kusuma dan Musaroh (2014) dan Alifah (2014) yang menghasilkan permodalan perbankan yang diukur dengan CAR dapat menaikkan nilai perusahaan, karena pemangku kepentingan menganggap modal perusahaan yang cukup dapat menutupi penyusutan aktiva atau memberikan laba perbankan yang besar.

$\mathrm{H}_{4}$ : Capital berpengaruh positif pada nilai perusahaan.

\section{METODE PENELITIAN}

Penelitian ini dilakukan pada perbankan yang terdaftar di Bursa Efek Indonesia (BEI) pada tahun 2014-2016 dengan mengambil data laporan keuangan perbankan yang dipublikasikan di website resmi BEI, yaitu www.idx.co.iddan mengakses situs masing-masing perusahaan. Obyek pada penelitian ini adalah nilai perusahaan pada perusahaan perbankan yang terdaftar di Bursa Efek Indonesia (BEI) pada tahun 2014-2016. Dalam penelitian ini terdapat dua jenis variabel, yaitu variabel dependen yang digunakan adalah nilai perusahaan (Y) dan variabel independen yang digunakan adalah Risk Profile $\left(\mathrm{X}_{1}\right)$, Good Corporate Governance $\left(\mathrm{X}_{2}\right)$, Earnings $\left(\mathrm{X}_{3}\right)$, dan Capital $\left(\mathrm{X}_{4}\right)$.

Variabel dependen $(\mathrm{Y})$ yang digunakan dalam penelitian ini adalah nilai perusahaan yang dihitung dengan rasio Tobin's $Q$. Rasio Tobin's Qadalah rasio nilai pasar aset perusahaan yang dapat dijabarkan sebagai perbandingan antara market value perusahaan dengan replacement cost aktiva suatu perusahaan 
(Chung dan Pruitt, 1994). Replacement cost adalah jumlah atau harga saham yang mestinya dibayarkan oleh entitas untuk mengganti suatu aktiva dengan aktiva yang sama pada masa saat ini. Rasio Tobin's $Q$ dinilai dapat memberikan informasi paling baik diantara pengukuran nilai perusahaan lainnya karena ukuran ini mampu menggambarkan beragam gejala aktivitas perusahaan, contohnya adanya pertentangan cross-sectional saat mengambil keputusan berinvestasi dengan diversifikasi, hubungan antara kepemilikan saham manajemen dengan nilai perusahaan, hubungan antara kinerja manajemen dengan keuntungan akuisisi,dividen, kompensasi, serta kebijakan pendanaan. Rasio Tobin's $Q$ merupakan perbandingan antara jumlah Market Value of Equity (MVE) dan Debt dengan Total Aset. Ketika nilai Tobin's $Q$ diatas 1 (satu), berarti nilai ganti aset perusahaan lebih kecil dari nilai pasar perusahaan sehingga akan menciptakan investasi baru, sedangkan jika nilai Tobin's $Q$ dibawah 1 (satu), maka ini berarti nilai perusahaan lebih kecil dari nilai ganti aset sehingga dapat dikatakan investasi dalam perusahaan belum menarik.

Risk Profile $\left(\mathrm{X}_{1}\right)$ Profil risiko perusahaan diukur secara luas dan kuantitaif, tersusun atas hasil penetapan kualitas risiko yang sesuai dengan tiap risiko. Profil risiko yang akan diteliti oleh peneliti adalah risiko kredit. Risiko kredit muncul ketika kewajiban yang seharusnya dipenuhi debitur tiap periodenya tidak mampu terpenuhi atau timbul suatu kerugian yang dipicu oleh kegagalan debitur dalam pemenuhan kewajibannya terhadap bank. Rasio Non Performing Loan Total Kredit adalah rasio antara jumlah total kredit dengan kualitas kurang lancar, diragukan, dan macet (kredit bermasalah), terhadap total kredit. Bank Indonesia 
(BI) melalui Peraturan Bank Indonesia (PBI) menetapkan bahwa rasio kredit bermasalah (NPL) adalah sebesar 5\%.

Good Corporate Governance $\left(\mathrm{X}_{2}\right)$ Berdasarkan Surat Edaran Bank Indonesia No 15/15/DPNP Tahun 2013 tentang penilaian Good Corporate Governance dilakukan upaya perbaikan dan peningkatan kualitas pelaksanaan Good Corporate Governance, yang mewajibkan bank secara berkala melakukan penilaian sendiri (self assessments). Penilaian tersebut mencakup 3 (tiga) aspek governance, yaitu : (1) Governance Structure; (2) Governance Process; dan (3) Governance Outcome. Adapun 3 (tiga) aspek Governance tersebut diterapkan pada 11 (sebelas) faktor penilaian yaitu: (1) Pelaksanaan tugas dan tanggung jawab Dewan Komisaris; (2) Pelaksanaan tugas dan tanggung jawab Direksi; (3) Kelengkapan dan pelaksanaan tugas komite; (4) Penanganan benturan kepentingan; (5) Penerapan fungsi kepatuhan; (6) Penerapan fungsi audit intern; (7) Penerapan fungsi audit ekstern; (8) Penerapan manajemen risiko termasuk sistem pengendalian intern; (9) Penyediaan dana kepada pihak terkait (related party) dan Penyediaan dana besar (large exposures); (10) Transparansi kondisi keuangan dan non keuangan bank, laporan pelaksanaan GCG dan pelaporan internal; dan (11) Rencana strategis bank. Penilaian kualitas corporate governance yang dikembangkan oleh Mahdan (2010) dibagi menjadi tiga kategori penilaian, yaitu pelaksanaan prinsipcorporate governance, kriteria penilaian sendiri (self assessment) atas pelaksanaan GCG bank, dan penilaian transparasi kondisi keuangan dan non keuangan bank yang belum diungkap dalam laporan lainnya. Tiga kategori penilaian ini berjumlah 19 jenis kriteria, yang mana di tiap- 
Desak Made Gita Lestari dan Made Gede Wirakusuma. Pengaruh ...

tiap kriteria akan memiliki peringkat good (3), fair (2), dan poor (1). Jumlah penilaian tersebut akan mencerminkan kualitas corporate governance bank, semakin besar skor yang di dapatkan oleh suatu bank, maka semakin baik pula kualitas corporate governance dari bank tersebut.

Earnings $\left(\mathrm{X}_{3}\right)$ rasio keuangan yang digunakan dalam pengukuran rentabilitas suatu perusahaan adalah Return On Assets (ROA). ROA adalah kemampuan dalam mendapatkan laba secara relatif jika dibandingkan dengan total aktivanya. Laba bersih yang digunakan dalam rasio adalah laba bersih sebelum adanya perhitungan pajak. Semakin besar ROA, maka semakin besar pula tingkat keuntungan yang dicapai oleh bank.

Capital $\left(\mathrm{X}_{4}\right)$ Agar bank dapat beroperasi, setidaknya setiap bank memiliki dan menyediakan modal minimalnya. Rasio kesehatan bank yang dapat digunakan untuk menilai tersedianya modal minimum bank adalah Capital Adequacy Ratio (CAR). CAR adalah rasio yang menjelaskan banyaknya kecukupan modal minimum yang diperlukan guna menutupi risiko kerugian yang akan muncul akibat penanaman aktiva mengandung risiko dan membiayai semua aset tetap serta inventory bank.

Teknik pengambilan sampel dalam penelitian ini adalah purposive sampling dengan kriteria sebagai berikut: (1) Perusahaan perbankan terdaftar di Bursa Efek Indonesia secara berturut-turut pada tahun 2014-2016; (2) Perbankan yang menerbitkan annual report-nya secara lengkap dari tahun 2014-2016 untuk keperluan analisis data; dan (3) Perusahaan menggunakan rupiah sebagai mata uang pelaporan, dengan tujuan agar laporan keuangan yang digunakan memiliki 
kesamaan mata uang pada saat perhitungan. Berdasarkan teknik tersebut, maka diperoleh sebanyak 43 perbankan sebagai sampel penelitian dimana 4 dari 43 bank tersebut merupakan bank BUMN dan 39 bank dan sisanya merupakan bank BUMS. Teknik analisis data yang digunakan dalam penelitian ini adalah uji statistik deskriptif, uji asumsi klasik, dan analisis regresi linier berganda. Adapun rumus analisis data tersebut digambarkan dalam persamaan regresi berikut.

$$
\mathrm{Y}=\alpha+\beta_{1} \mathrm{X}_{1}+\beta_{2} \mathrm{X}_{2}+\beta_{3} \mathrm{X}_{3}+\beta_{4} \mathrm{X}_{4}+\varepsilon
$$

Keterangan:

$\begin{array}{ll}\mathrm{Y} & : \text { Nilai Perusahaan } \\ \alpha & : \text { Nilai Konstanta } \\ \beta_{1}, \beta_{2}, \beta_{3}, \beta_{4} & : \text { Koefisien Regresi Variabel Independen } \\ \mathrm{X}_{1} & : \text { Risk Profile } \\ \mathrm{X}_{2} & : \text { Good Corporate Governance } \\ \mathrm{X}_{3} & : \text { Earnings } \\ \mathrm{X}_{4} & : \text { Capital } \\ \varepsilon & : \text { Error term, yaitu tingkat kesalahan penduga dalam penelitian }\end{array}$

\section{HASIL DAN PEMBAHASAN}

Statistik deskriptif dapat menyajikan informasi tentang variabel-variabel dalam penelitian, antara lain nilai minimum, nilai maksimum, nilai rata-rata, dan simpangan baku. Adapun output statistik deskriptif setiap variabel disajikan pada Tabel 1.

Tabel 1.

Hasil Statistik Deskriptif Variabel Penelitian

\begin{tabular}{|c|c|c|c|c|c|}
\hline Variabel & $\mathbf{N}$ & Min. & Maks. & Rata-rata & Simpangan Baku \\
\hline Nilai Perusahaan & 129 & 0,50 & 18,64 & 3,05 & 2,15 \\
\hline Risk Profile & 129 & 0,08 & 5,45 & 1,88 & 1,27 \\
\hline GCG & 129 & 1,37 & 2,84 & 2,36 & 0,32 \\
\hline Earnings & 129 & 0,24 & 12,00 & 5,05 & 1,95 \\
\hline Capital & 129 & 6,82 & 48,38 & 19,32 & 5,67 \\
\hline
\end{tabular}


Berdasarkan Tabel 1, diketahui bahwa terdapat lima variabel penelitian, yaitu risk profile, good corporate governance, earnings, capital, dan nilai perusahaan yang diproksikan dengan Tobin's $Q$. Data pada variabel nilai perusahaan (Y) berjumlah 129 dengan nilai rata-rata 3,05 dan simpangan baku sebesar 2,15. Nilai minimum pada variabel ini diperoleh PT Bank Pembangunan Daerah Banten Tbk. tahun 2016 sebesar 0,50, sedangkan nilai maksimum diperoleh Bank Central Asia Tbk tahun 2015 dan Bank Mandiri (Persero) Tbk tahun 2015 sebesar 18,64.

Data pada variabel risk profile $\left(\mathrm{X}_{1}\right)$ berjumlah 129 dengan nilai rata-rata sebesar 1,88 dan simpangan baku sebesar 1,27. Nilai minimum pada variabel ini diperoleh PT Bank Ina Persada Tbk. tahun 2015 sebesar 0,08, sedangkan nilai maksimum diperoleh PT Bank JTrust Indonesia Tbk. tahun 2014 sebesar 5,45. Data pada variabel good corporate governance - GCG $\left(\mathrm{X}_{2}\right)$ berjumlah 129 dengan nilai rata-rata sebesar 2,36 dan simpangan baku sebesar 0,32. Nilai minimum pada variabel ini diperoleh PT Bank Agris Tbk. tahun 2015 sebesar 1,37, sedangkan nilai maksimum diperoleh PT Bank Tabungan Negara (Persero) Tbk tahun 2014 dan 2015 serta PT Bank China Construction Bank Indonesia Tbk tahun 2014 dan 2015 sebesar 2,84.

Data pada variabel earnings $\left(\mathrm{X}_{3}\right)$ berjumlah 129 dengan nilai rata-rata 5,05 dan simpangan baku sebesar 1.95. Nilai minimum pada variabel ini diperoleh PT Bank JTrust Indonesia Tbk. tahun 2014 sebesar 0,24, sedangkan nilai maksimum diperoleh PT Bank Tabungan Pensiunan Nasional Tbk tahun 2016 sebesar 12,00. Data pada variabel capital $\left(\mathrm{X}_{4}\right)$ berjumlah 129 dengan nilai rata-rata 19,32 dan 
simpangan baku sebesar 5,67. Nilai minimum pada variabel ini diperoleh PT Bank Agris Tbk tahun 2016 sebesar 6,82, sedangkan nilai maksimum diperoleh PT Bank Nationalnobu Tbk tahun 2014 sebesar 48,38.

Analisis data dalam penelitian ini memakai teknik analisis regresi berganda. Analisis regresi berganda bertujuan untuk menunjukkan arah dan besarnya pengaruh risk profile, good corporate governance, earnings, dan capital baik secara simultan maupun parsial terhadap nilai perusahaan perusahaan perbankan yang terdaftar di BEI. Hasil analisis regresi linear berganda disajikan pada Tabel 2 .

Tabel 2.

Hasil Analisis Regresi Linear Berganda

\begin{tabular}{|c|c|c|c|c|c|}
\hline \multirow[t]{2}{*}{ Model } & \multicolumn{2}{|c|}{$\begin{array}{l}\text { Unstandardized } \\
\text { Coefficients }\end{array}$} & \multirow{2}{*}{$\begin{array}{c}\begin{array}{c}\text { Standardized } \\
\text { Coefficients }\end{array} \\
\text { Beta }\end{array}$} & \multirow[t]{2}{*}{$\mathbf{t}$} & \multirow[t]{2}{*}{ Sig. } \\
\hline & B & Std. Error & & & \\
\hline 1 (Constant) & 0,056 & 0,050 & & 1,115 & 0,267 \\
\hline $\mathrm{X}_{1}$ & $-0,223$ & 0,059 & $-0,214$ & $-3,810$ & 0,000 \\
\hline $\mathrm{X}_{2}$ & 0,308 & 0,054 & 0,325 & 5,714 & 0,000 \\
\hline$X_{3}$ & 0,299 & 0,070 & 0,284 & 4,304 & 0,000 \\
\hline $\mathrm{X}_{4}$ & 0,416 & 0,061 & 0,382 & 6,844 & 0,000 \\
\hline
\end{tabular}

F hitung $\quad: 68,458$

Signifikansi F $\quad: 0,000$

R Square $\quad: 0,688$

Adjusted R Square $\quad: \quad 0,678$

Sumber: Data diolah, 2018.

Koefisien determinasi pada model regresi linear berganda dilihat dari nilai Adjusted $R$ Square sebesar 0,678 , yang berarti secara bersamaan, variasi variabel risk profile, good corporate governance, earnings, dan capital menjelaskan bahwa variabel tersebut berpengaruh signifikan sebesar 0,678 atau 67,8\%, sedangkan sisanya sebesar $32,2 \%$ dipengaruhi oleh variabel lain yang tidak masuk dalam model. 
Uji $\mathrm{F}$ merupakan tahapan awal mengidentifikasi model regresi yang diestimasi layak atau tidak. Berdasarkan Tabel 2 diatas, diperoleh nilai signifikansi sebesar 0,000 dimana nilai sig. $0,000<0,05$, maka hal ini berarti bahwa seluruh variabel mampu memprediksi dan menjelaskan fenomena nilai perusahaan pada perusahaan perbankan dan model regresi yang digunakan dianggap layak uji.

Tabel 2 menunjukkan koefisien risk profile $\left(\beta_{1}\right)$ sebesar -0,223 dengan nilai signifikansi 0,000 lebih kecil dari $\alpha=5$ persen $(0,000<0,05)$, maka $\mathrm{H}_{0}$ ditolak dan $\mathrm{H}_{1}$ diterima. Hasil ini menunjukkan bahwa risk profile berpengaruh negatif dan signifikan pada nilai perusahaan. Semakin tinggi tingkat risikonya, maka kualitas pengelolaan risikonya sangat tidak memadai. Menurut Agustini dan Wardoyo (2015), tinginya risiko pada perbankan, terutama risiko reputasi dan risiko kredit dapat memberikan informasi negatif pada pemangku kepentingan yang akan berakibat pada nilai perusahaan di perbankan, hal ini berarti sejalan dengan hasil penelitian. Dikatakan bad news karena investor akan berasumsi jika besarnya risiko akan memunculkan keraguan sehingga memprediksi bahwa risiko yang akan menurunkan nilai perusahaan (Repi dkk, 2016). Ketidakmampuan dalam mengelola risiko akan menghambat kegiatan operasional perbankan yang kemungkinan akan mengalami kebangkrutan. Semakin tinggi risk profile, maka akan menurunkan kepercayaan nasabah (investor) yang akan berdampak pada harga saham yang dinilai rendah di pasar dan dapat menurunkan nilai perusahaan perbankan. 
Tabel 2 menunjukkan koefisien good corporate governance $\left(\beta_{2}\right)$ sebesar 0,308 dan tingkat signifikansi 0,000 dengan $\alpha=5 \%(0,000<0,05)$, artinya $\mathrm{H}_{0}$ ditolak, sebaliknya $\mathrm{H}_{2}$ diterima. Ini berarti bahwa good corporate governance secara parsial berpengaruh positif dan signifikan pada nilai perusahaan.Hasil penilaian dari GCG ini akan memberikan informasi seberapa jauh manajemen bank sudah mengaplikasikan prinsip-prinsip GCG dalam mengatur perusahaannya, jika nilai GCG mengalami penurunan maka akan memengaruhi penurunan nilai perusahaan perbankan. Menurut Perdana (2014) dan Putra (2014) mengemukakan nilai perusahaan bisa meningkat dengan menerapkancorporate governance yang baik. Good Corporate Governance ditujukan sebagai alat kontrol perusahaan untuk mengurangi terjadinya konflik keagenan dalam perusahaan. Menurut hasil penelitian dari Randy dan Juniarti (2013), menghasilkan pengaruh yang positif GCG pada nilai perusahaan melalui GCG score. GCG score yang tinggi mencerminkan bahwa perbankan dalam menerapkan GCG dilakukan dengan baik. Khan (2011) mengungkapkan corporate governancedapat menaikkan nilai perusahaan dengan akuntabilitas dari manajer dandari peningkatan kinerja perusahaan.

Tabel 2 menunjukkan koefisien earnings $\left(\beta_{3}\right)$ sebesar 0,299 dengan tingkat signifikansi 0,000 dengan $\alpha=5 \%(0,000<0,05)$, maka $\mathrm{H}_{0}$ ditolak dan $\mathrm{H}_{3}$ diterima. Ini berarti bahwa earnings secara parsial berpengaruh positif dan signifikan padanilai perusahaan. Tingginya nilai ROA, maka posisi perusahaan dalam hal pengelolaan aset yang dimiliki untuk mendapatkan laba juga semakin baik. Lestari dan Sugiharto (2007) berpendapat, nilai ROA dikatakan baik jika lebih dari $2 \%$. 
Menurut hasil penelitian Repi dkk (2016) dan Asiri dan Salwa (2014), profitabilitas dengan rasio ROA dapat memberikan sinyal baik ke investor yang akan berdampak pada meningkatnya nilai perusahaan perbankan. Earnings yang tinggi dapat dijadikan sebagai informasi good news untuk pemegang saham karena manajemen dianggap mampu dalam mengelola aset perusahaan.

Tabel 2 menunjukkan koefisien capital $\left(\beta_{4}\right)$ sebesar 0,416 dengan tingkat signifikansi 0,000 dengan $\alpha=5 \%(0,000<0,05)$, maka $\mathrm{H}_{0}$ ditolak sebaliknya $\mathrm{H}_{4}$ diterima. Ini berarti bahwa capital secara parsial berpengaruh positif dan signifikan pada nilai perusahaan. Semakin tinggi nilai CAR, maka semakin baik pula pembiayaan atas aktiva berisiko yang dimiliki bank sehingga dapat mengurangi kemungkinan adanya kebangkrutan. Sesuai peraturan Otoritas Jasa Keuangan, permodalam minimum yang harus dimiliki bank adalah $8 \%$. Menurut Fahmi (2015), CAR menggambarkan kesanggupan bank menutupi risiko kerugian dari aktivitas yang dilaksanakan serta kemampuan bank untuk mendanai kegiatan operasionalnya. Hasil riset ini sejalan dengan hasil riset Hidayat (2014) yang mengemukakan CAR berpengaruh positif pada nilai perusahaan. Pertumbuhan laba yang dihasilkan akan memberikan sinyal bagi investor tentangsituasi perusahaan yang baik, sehingga investor tertarik membeli saham perusahaan, dimana naiknya nilai pasar perusahaan akan diikuti dengan kenaikkan nilai perusahaan tersebut (Fama, 1978)

\section{SIMPULAN}

Berdasarkan hasil penelitian yang diperoleh melalui pengujian statistik serta pembahasan, maka dapat disimpulkan bahwa variabel risk profile berpengaruh 
negatif pada nilai perusahaan. Sedangkan variabel good corporate governance, earnings, dan capital berpengaruh positif dan signifikan pada nilai perusahaan.

Berdasarkan hasil penelitian dan simpulan diatas, maka saran yang dapat diberikan adalah diharapkan perbankan tetap menjaga kesehatan bank sesuai dengan metode RGEC yang sudah ditetapkan Bank Indonesia. Selain itu, pihak eksternal diharapkan agar selalu memperhatikan tingkat kesehatan bank dalam proses pengambilan keputusan terkait kegiatan keuangan dan investasi. Penambahan atau penggunaan rasio lain untuk mengukur kinerja keuangan dengan variabel yang relevan juga dapat dilakukan dalam penelitian selanjutnya.

\section{REFERENSI}

Agustini, R. M., \& Wardoyo. 2015. Dampak Implementasi RGEC Terhadap Nilai Perusahaan yang Go Public di Bursa Efek Indonesia. KINERJA, 19(2), 126-138.

Alifah, Y. B. 2014. Pengaruh CAR, NPL, BOPO, dan LDR Terhadap Profitabilitas Bank (ROA) Pada Perusahaan Perbankan Yang Terdaftar Di Bursa Efek Indonesia Periode 2009-2012. Skripsi.

Arifin, J., Suhadak, \& Astuti, E. S. 2013. The Influence of Corporate Governance on Financial Performance and Firm Value of Bank Sector Companies Listed at Indonesia Stock Exchange in Period 2008-2012. International Journal of Management and Administrative Sciences (IJMAS), 3(6), 01-17.

Asiri, Batool K., dan Salwa, A. Hameed. 2014. Financial Ratios and Firm's Value in the Bahrain Bourse. Research Journal of Finance and Accounting, 5(7), pp:1-11.

Bank Indonesia. 2004. Peraturan Bank Indonesia No. 6/10/PBI/2004 Tentang Sistem Penilaian Tingkat Kesehatan Bank Umum. Peraturan Bank Indonesia. Retrieved from http://www.bi.go.id/id/peraturan/arsipperaturan/Perbankan2004/pbi_61004.pdf

Bank Indonesia. 2011a. Peraturan Bank Indonesia Nomor: 13/1/PBI/2011 Tentang Penilaian Tingkat Kesehatan Bank Umum.

Bank Indonesia. 2011b. Surat Edaran Bank Indonesia No. 13/ 24/DPNP. 
Bank Indonesia. 2013. Surat Edaran Bank Indonesia No. 15/15/DPNP.

Bertinetti, G. S., Cavezzali, E., \& Gardenal, G. 2013. The Effect of the Enterprise Risk Management Implementation on the Firm Value of European Companies. SSRN Electronic Journal, (10), 1-22. https://doi.org/10.2139/ssrn.2326195

Brahmananda, I. B., \& Suputra, I. D. G. D. 2017. Analisis Komparatif Tingkat Kesehatan Bank Antara CAMELS dan RGEC PT Bank BPD Bali Tahun 2012-2014. Jurnal Akuntansi Universitas Udayana, 19(1), 51-80.

Budisantoso, T., \& Nuritomo. 2014. Bank dan Lembaga Keuangan Lain.

Chung, K. H., \& Pruitt, S. W. 1994. A Simple Approximation of Tobin's q. Financial Management. https://doi.org/10.2307/3665623

Dewi, N. M. W. P., dan Wiratmaja, I. D. N. 2017. Pengaruh Profitabilitas dan Solvabilitas Pada Audit Delay Dengan Ukuran Perusahaan Sebagai Variabel Pemoderasi. E-Jurnal Akuntansi Universitas Udayana, 20(1), 409-437.

Fahmi, I. 2015. Manajemen Perbankan: Konvensional dan Syariah. Jakarta: Mitra Wacana Media.

Fama, E. F. 1978. The Effect of a Firm's Investment and Financing Decision on the Welfare of its Security Holders. American Economic Review,vol. 68

Forum for Corporate Governance in Indonesia. 2001. Indonesian Company Law. Available on-line at www.fcgi.org.id

Gherghina, Ş. C. 2015. Corporate Governance Ratings and Firm Value : Empirical Evidence from the Bucharest Stock Exchange. International Journal of Economics and Financial Issues, 5(1), 97-110.

Hermuningsih, S., dan Wardani, D. K. 2009. Faktor-Faktor yang Mempengaruhi Nilai Perusahaan pada Perusahaan yang Terdaftar di Bursa Efek Malaysia dan Bursa Efek Indonesia. Jurnal Siasat Bisnis, 13(2), 173-183.

Hidayat, M. 2014. Pengaruh Rasio Kesehatan Perbankan Terhadap Nilai Perusahaan (Studi Kasus Pada Perbankan Yang Terdaftar di Bursa Efek Indonesia). Jurnal Ekonomi Dan Informasi Akuntansi, 4(1), 41-47.

Jama'an. 2008. Pengaruh Mekanisme Corporate Governance dan Kualitas Kantor Akuntan Publik Terhadap Integritas Informasi Laporan Keuangan (Studi pada Perusahaan Publik yang Listing di BEJ). Tesis Jurusan Akuntansi 
Program Studi Magister Sains Akuntansi Universitas Diponegoro. Semarang.

Jensen, M. C., \& Meckling, W. H. 1976. Theory of the Firm: Managerial Behavior, Agency Costs and Ownership Structure. Journal of Financial Economics, 3, 305-360. https://doi.org/10.1016/0304-405X(76)90026-X

Jogiyanto. 2014. Teori Portofolio dan Analisis Investasi Edisi Kesembilan. Yogyakarta: BPFE.

Kaligis, Y. W. 2013. Analisis Tingkat Kesehatan Bank Dengan Menggunakan Metode Camel Pada Industri Perbankan Bumn Yang Terdaftar Di Bursa Efek Indonesia. Jurnal EMBA, 1(3), 263-272.

Keown, Arthur J., et al. 2011. Manajemen Keuangan: Prinsip-Prinsip Dasar dan Aplikasi Jilid 1. Tenth Edition First Publishion. PT. Indeks.

Khan, Humera. 2011. A Literature Review of Corporate Governance. International Conference on E-Business, Management and Economics IPEDR, 25(1), pp: 1-5.

Kusuma, I., \& Musaroh. 2014. Pengaruh Rasio Keuangan Terhadap Nilai Perusahaan Perbankan yang Terdaftar di Bursa Efek Indonesia. Jurnal Manajemen Bisnis Indonesia, 3(6).

Lestari, Maharani Ika., dan Sugiharto, Toto. 2007. Kinerja Bank Devisa dan Bank Non Devisa dan Faktor-Faktor yang Mempengaruhinya. Proceeding PESAT (Psikologi, Ekonomi, Sastra, Arsitek \& Sipil), vol. 2. Fakultas Ekonomi Universitas Gunadarma.

Mahdan. 2010. Analisis Korelasi Pelaksanaan Good Corporate Governance Terhadap Kualitas Kredit Perbankan di Indonesia. Jakarta: Program Studi Maksi FEUI.

Menicucci, E., \& Paolucci, G. 2016. The determinants of bank profitability: empirical evidence from European banking sector. Journal of Financial Reporting and Accounting (Vol. 14). https://doi.org/10.1108/JFRA-052015-0060

Otoritas Jasa Keuangan. 2016. Peraturan Otoritas Jasa Keuangan No. 55/POJK.03/2016 tentang Penerapan Tata Kelola Bagi Bank Umum. Retrieved from www.ojk.go.id

Perdana, Ramadhan Sukma. 2014. Analisis Pengaruh Corporate Governance Terhadap Nilai Perusahaan Perbankan. Diponegoro Journal of Accounting, 3(3), pp:1-13. 
Pratama, I Gede Gora Wira., dan Wirawati, Ni Gst. Putu. 2016. Pengaruh Struktur Modal dan Profitabilitas Terhadap Nilai Perusahaan dengan Kepemilikan Manajerial sebagai Pemoderasi. E-Journal Akuntansi Universitas Udayana, 15(3), 1796-1825.

Putra, Adrie. 2014. The Impact of Implementation Good Corporate Governance to Firm Value (Evidence from Indonesia Public Banking Sector). Rev. Integr. Bus. Econ. Res. 4(1), pp:95-102.

Randy, V., \& Juniarti. 2013. Pengaruh Penerapan Good Corporate Governance Terhadap Nilai Perusahaan Yang Terdaftar Di Bursa Efek Indonesia 20072011. Business Accounting Review, 1(2), 306-318.

Repi, Switli., Sri Murni., dan Decky Adare. 2016. Faktor-Faktor yang Mempengaruhi Nilai Perusahaan Subsektor Perbankan pada BEI dalam Menghadapi MEA. Jurnal EMBA, 4(1), pp:181-191.

Setiani, R. 2013. Pengaruh Keputusan Investasi, Keputusan Pendanaan, Dan Tingkat Suku Bunga terhadap Nilai Perusahaan Pada Perusahaan Otomotif Yang Terdaftar Di Bursa Efek Indonesia, 1, 1-10. https://doi.org/10.1017/CBO9781107415324.004

Setyapurnama, E. H. dan Nopratiwi. 2004. Peran Praktek Corporate Governance sebagai Moderating Variable dari Pengaruh Earnings Management Terhadap Nilai Perusahaan. Jurnal Ekonomi dan Bisnis, 7(1), 15-21.

Sisharini, Nanik. 2013. Pengaruh Tingkat Kesehatan Bank dan Faktor Fundamental Makro Ekonomi Terhadap Nilai Perusahaan pada Perusahaan Perbankan yang Tercatat di Bursa Efek Indonesia. Disertasi. Universitas Merdeka Malang.

Spence, M. 1973. Job Market Signalling. The Quarterly Journal of Economics, 87(3).

Utami, Santi Budi. 2015. Perbandingan Analisis CAMELS dan RGEC dalam Menilai Tingkat Kesehatan Bank pada Unit Usaha Syariah Milik Pemerintah (Studi Kasus: PT Bank Negara Indonesia, Tbk. Tahun 20122013. Skripsi Akuntansi.

Wida, N. P., \& Suartana, I. W. 2014. Pengaruh Kepemilikan Manajerial dan Kepemilikan Institusional pada Nilai Perusahaan. E-Jurnal Akuntansi Universitas Udayana, 9(3), 575-590. 